\section{A bouquet}

The appearance of my name among crossword winners in ET33 Jan 93) prompts this belated but sincere thanks not only for a most valuable prize, The Oxford Companion to the English Language, which I have only had time so far to savour but also for yet another issue containing the best sort of academic writing - things ordinary practitioners can understand, learn from and largely agree with.

H. E. Bell, Reading, England

\section{Hybrids past and present}

Reading Mrs Raana G. N. Sheikh's letter (Post \& Mail, ET33 Jan 93) on English Medium Schools and English Hybridization, I could not help recalling to mind how the English dealt with NormanFrench. Here is an example:

le volunt de chescum home sera prise on construe en le pluis large measure que il poet estre prise reasonablement pur le benefit de le alme de le mort Anon. (1502) Keil. 43b.

Megarry's two books on Miscellany-at-Law contains quite a number of such gems. The use of Latin phrases in the legal field attests, to this day, how one language borrows from another language.

V.C.R.A.C. Crabbe, Faculty of Law.

University of the West Indies, Bridgetown, Barbados

\section{A point of style}

I was recently a student on an MSc course in a British University on the use of computers in education. The wording of one of our assignments was: 'Discuss: When they were first developed, rule-based expert systems were thought to be both capable of achieving the same results as human expertise and also being a reasonable model of human problem solving and reasoning.'

$M y$ request for the assignment to be expressed in adequate English was turned down by the tutor who set it, then by the Course Director, and even by the Vice-Chancellor of the University when I appealed to him. He informed me that no-one else had expressed any problems, and I should get on with it. Is it possible that the dissemination of the practice of using good English is a power struggle as well as a broadly educational project?!

David Yates,
Preston, Lancashire, England

\section{On verbing, TESOL, trivia and telephones}

I have four separate topics:

First: the enclosed cartoon speaks volumes on the subject of the use of other parts of speech as verbs in present-day English. It is a syndicated cartoon and appeared in many newspapers on January 25. [In the strip, the characters are talking about liking to 'verb' words, and one says that 'verbing weirds language'. $E d$.]

Second: the article on TESOL is hard-hitting but basically fair, and I believe the writer has a good point when he says that if ESL/EFL teaching is not to be dominated by the British (I think it is anyway) then TESOL will have to pull its socks up. By the way, I do not believe that TESOL as an organization suppresses dissenting views.

Third: As Benson says about TESOL, that it is too preoccupied with trivia to the exclusion of major themes, so might the same thing apply to ET sometimes (Example: pp. $36-37$ of ET33). Although I enjoy examples of verbing etc., the usage 'bad' has been around for a very long time. Let's not lose sight of the major trends.

Fourth: Re Dennis Baron's article, the phone listings for exterminators have long been a source of good alpha numbers: Call 354-PEST, for example or 752-DEAD. There really is an art to this. In Seattle, people can report abusers of the car pool lane by calling 1-800-BE-AHERO (altered on some signs to 1-800-BE-A-JERK). Truckers have bumper stickers advising motorists 'Am I driving safely? If not call ....' so now there are others: 'Don't like my driving' Call 1-800-EAT-SHIT.' Verily it takes all sorts ....

Thank you very much for your time and attention. I enjoy ET very much and wish the publication long success.

Ian C. Palmer, The Latin American Scholarship Program of American

Universities, Cambridge MA, U.S.A.

\section{TESOL: 23,000 members minus one}

Morton Benson's 'The Trouble with TESOL' (ET33) ranks as one of the most percipient and honest articles I have read in a long time. Let me explain why I have used the word 'honest'. I was a member of TESOL for a few years, even publishing in TESOL Quarterly and TESOL Newsletter, but finally decided that its publications had nothing of interest for me as a linguist nor as an ESL instructor. Thus, I decided to drop out of the organization a couple of years back for precisely those reasons advanced by Benson: (1) boring 
(my word) discussions of trivial, insignificant (his words) points, (2) disdain (my word) for the intricacies of English (consider, e.g., hard-boiled egg and hotbuttered toast, but I would like my toast hot and buttered, and not *I would like my egg hard and boiled [examples made famous by T.F. Mitchell, a Professor Emeritus at the University of Leeds, but rarely discussed by TESOL authors]), and (3) an intolerance for opposing viewpoints (his words). If Benson had offered his fine paper for publication in TESOL Quarterly, it would have certainly, in my opinion, been laughed out of the business. Can there be any doubt that the offcers and editors of the organization are not exactly going to be pleased with Benson (nor with me for agreeing with his observations)? But then, I am no longer a member!

I find one weak point with just about all applied linguistic outlets today, viz. that advanced learners are not considered important. In this regard, Benson's faultinding of TESOL can safely be generalized. Applied linguists (dealing with any language) should, for example, be writing research articles on how best to teach idioms. (I assume idiomaticity to be a linguistic universal.) Students always want to know why 'John kicked the bucket' means 'John died'. I usually try in my answer to relate this idiom to other idioms such as 'John kicked off', but somehow, I wind up telling them just to memorize idioms (this approach is inadequate, but I feel I have no other choice). Benson is right that ESL students 'deserve better' (p.8). Only yesterday a foreign student asked me why

Readers' letters are welcomed. $E T$ policy is to publish as representative and informative a selection as possible in each issue. Such correspondence, however, may be subjected to editional adaptation in order to make the most effective use of both the letters and the space available.

the audience laughed at the following sentence on a humorous T.V. show: 'Johnny,' his mother says, 'you have to finish every bean and pea (pee - get it?) on the plate!' These are the kinds of English sentences about which advanced learners are curious and about which little or no information is available for explicative purposes in our professional journals. As I see it, Benson is absolutely right in his overall assessment of the field. We should be concentrating on how best to teach total communicative competence in a foreign language.

Alan S. Kaye,
California State University,
Fullerton, California, USA

\section{TESOL: Benson replies to Bayley}

In her response (ET34 Apr 93) to my article, Susan Bayley claims to speak on 'behalf of the TESOL membership and the Executive Board'. While she may be speaking for the Executive Board, how does she presume to speak for the 23,000 members of TESOL? Would she reprint or summarize the article on the pages of a TESOL organ or would she invite me to address the members of TESOL so that they might be able to make their own assessment?

Bayley asserts that I do 'not seem to appreciate the depth and breadth' of TESOL and that I 'ought to contribute' to the organization. In fact, I am well acquainted with TESOL. Over ten years ago I joined the organization and began to read its journals (even before I began to read English Today). I have attended national and local meetings, have worked with TESOL members at the University of Pennsylvania on a program for English teachers from Eastern Europe, and have had contributions published in the TESOL Quarterly (22, 1988 and 23, 1989).
Bayley's cavalier dismissal of English grammar and usage as a 'narrow interest' encapsulates what is wrong with TESOL. The point is that grammar and usage are the foundation, the essence, the sine qua non of language teaching and learning. Although given every opportunity to do so by English Today, Susan Bayley leaves unanswered my major criticisms: TESOL woefully neglects the grammar of English; TESOL dissipates its energies on trivial discussion of methodology and language acquisition; TESOL is intolerant of dissenting viewpoints. TESOL is in need of leadership.

Morton Benson, University of Pennsylvania, Philadelphia, Pennsylvania, USA

\section{Translation English}

In your very interesting article 'Models of English' (ET32, Oct 92), you include as 'Englishes' the many varieties of English spoken as a second language, but you miss an important related form - Translation English. By this I do not mean the English used by someone who is 'thinking' in French or Chinese and then mentally translating into English, or the English used by a French person translating a French text into English (cf the often amusing signs for tourists that can be seen in France and Quebec). I mean the English used by native speakers of English when translating from other languages.

Translation English is often overlooked, yet it is everywhere. The Bible, The Interpretation of Dreams (Freud's Traumdeutung), the Revised Statutes of Quebec these are all written in Translation English. You do mention 'Quebec English' on your wheel of Englishes. If this means the English spoken not as a second language by Quebec Francophones but as a first language by Quebec Anglophones under the influence of their French 
environment, then it might seem that you have accounted for the phenomenon to which I am referring. But I think that's something different - the incorporation of Translation English into the Canadian Standard English of Quebec Anglophones, yielding what Görlach might call a subregional semi-standard.

When Quebec Anglophones write about an 'anti-government manifestation' (instead of 'demonstration'), they are not translating. Just as I am not translating when I use any of the thousands of Latin-derived words which first appeared in our language in translations from Latin several hundred years ago. If there is a Quebec English, that is because words like 'manifestation' in the French sense have now been incorporated into the usage of unilingual Anglophones. It is no longer just a matter of bilingual Anglophones using them.

But does Translation English the English that appears in translations - actually exist? Is there really a set of lexical, syntactic and morphological features that appear in translations, distinguishing them from nontranslations? Some people do think that even native speakers with professional training in translation tend to use English somewhat differently in their translations and in their original writing.

But perhaps the English I use when I translate is just an idiosyncratic style of my own. Would a hundred different Englishspeaking translators all deviate from their usual English in the same ways when producing their translations? I think so, but it's an open question, and in fact this is the type of question now being addressed in the new field of Translation Studies.

One important factor is that after a given community has been translating from a particular other language for a long time, a body of standard equivalents appears, and these become sanc- tioned in the bilingual dictionaries which translators consult. Standard equivalents are now also passed on in translation schools and in translation bureaus where translators see each other's work.

When translators use standard equivalents, the result is sometimes an unidiomatic collocation or an extension of the existing meaning of an English word. A simple example is the habit of rendering the French verb 'étudier' as 'study'. In reality, 'étudier' has a much broader meaning than 'study' and can often be idiomatically and accurately rendered only by verbs such as 'consider' 'go over' 'investigate' or 'examine'. It is not as closely connected with schoolwork or scholarly/scientific activity as 'study', and does not always imply as thorough a degree of examination as 'study'.

Professional non-literary translators try to combat (and now are trained to combat) the tendency to always use one of the standard equivalents of a sourcelanguage word. But psychologically speaking, standard equivalents require the least effort, and of course, much of the time they work perfectly well. The result is that translators - even good ones - regularly lapse into unusual uses of standard equivalents. (In literary translation, these unusual uses are often valued as creative innovations, but in administrative-technicalcommercial translation, they are generally speaking undesirable and seen as errors.)

That standard equivalents are regularly overused is a view widely held among translators, revisers and trainers of translators (I have done all three jobs for the past 18 years in the Canadian federal government's Translation Bureau). This view still needs to be verified quantitatively. My guess is that if a large computerized corpus of French-English translations could be assembled, the verb 'study' would be seen to occur much more frequently in
Translation-from-French English than in other English.

As I see it, there are four possible hypotheses from which a consideration of Translation English might start. Under the strongest of them, there will be a common set of deviations within a group of translators even if (a) some are translating from Chinese and others from French, and (b) some of them, when not translating, use British Standard English while others use Canadian Standard English. In short, 'Translation English' would exist as a single entity - perhaps a circle within 'International English' on Manfred Görlach's wheel diagram. This possibility seerms unlikely on the face of it, but should be considered nevertheless.

Two weaker hypotheses would eliminate either condition (a) or condition (b). Eliminating (b), we would hypothesize the existence of entities such as Canadian Translation English and British Translation English. I'm not sure where these would fit on Görlach's wheel. On your wheel, I suppose Canadian Translation English would simply be a spoke in the Canadian English segment of the wheel, along with Newfoundland and Quebec Englishes.

Eliminating condition (a) would give entities like Translated-French English and Translated-Chinese English. These would be comparable to English spoken as a second language. That is, the various Translation Englishes would be Englishes used by native speakers writing or speaking as if they were not native speakers. They would be 'mixes' on Görlach's wheel. As mentioned above in connection with standard equivalents, an external norm already exists for such entities, in the form of bilingual dictionaries, and the potential for standardization is now being strengthened by increased professionalization and contacts amongs translators. 
The weakest hypothesis would eliminate both (a) and (b), yielding entities such as TranslatedFrench British English, characterized by the set of features common to all translations from French by writers who, when not translating, use British English.

An obvious alternative to all this would be to say that translated vs non-translated is simply a separate dimension of classification, like written $v s$ oral or legal $v s$ religious. The peculiarities found in the translation of a French statute could then be described as features which appear when a speaker of one of the Englishes listed on Görlach's wheel, or your own, uses that English to translate a legal text. In other words, translation features would be related to a situation of use rather than to a user.

With that approach, however, it would no longer be possible to justify inclusion of secondlanguage Englishes on the wheels. Why categorize in one way the English used by native speakers of French, but in a completely different way the English written by native speakers of English writing under the influence of a French text? What do you think?

Brian Mossop, Toronto, Canada

\section{CROSSWORLD}

\section{ET34 CrossworLd Solution}

\begin{tabular}{|c|c|c|c|c|c|c|c|c|c|c|c|c|c|c|}
\hline $\mathrm{H}$ & 0 & $M$ & 0 & $\mathrm{G}$ & $\mathrm{R}$ & A & $P$ & $\mathrm{H}$ & & A & $\mathrm{G}$ & A & $P$ & $E$ \\
\hline A & & & & I & & D & & & & $U$ & & $P$ & & A \\
\hline C & A & $S$ & $\mathrm{~T}$ & L & $E$ & D & & S & A & $T$ & $\mathrm{R}$ & A & $P$ & $S$ \\
\hline I & & C & & L & & I & & $P$ & & 0 & & $\mathbf{R}$ & & I \\
\hline$E$ & C & $\mathrm{H}$ & 0 & . & $s$ & C & $\mathrm{R}$ & A & $P$ & $M$ & $E$ & $T$ & A & $\mathrm{L}$ \\
\hline$N$ & & A & & ${ }^{3} S$ & & $\mathrm{~T}$ & & $\mathrm{~N}$ & & 0 & & & & $Y$ \\
\hline D & $E$ & $\mathrm{~N}$ & 1 & $E$ & $\mathrm{R}$ & & ' $\mathrm{R}$ & 1 & B & B & 0 & $\mathrm{~N}$ & $S$ & \\
\hline A & & C & & A & & $E$ & & C & & I & & $E$ & & ${ }^{18} \mathrm{P}$ \\
\hline & $P$ & $E$ & A & $S$ & A & $N$ & $\mathrm{~T}$ & & $\mathrm{~F}$ & L & 0 & W & $E$ & $\mathrm{R}$ \\
\hline L & & & & 0 & & $T$ & & $\mathrm{~T}$ & & $E$ & & C & & $E$ \\
\hline $\mathrm{B}^{3}$ & $N$ & ${ }^{4} \mathrm{G}$ & $E$ & $N$ & $E$ & $R$ & 0 & $\mathrm{U}$ & $S$ & & 5 & A & $S$ & $\mathrm{~S}$ \\
\hline$N$ & & $\mathrm{~L}$ & & A & & A & & $M$ & & $\mathrm{~L}$ & & $S$ & & $\mathrm{E}$ \\
\hline $\mathrm{G}$ & $\mathrm{R}$ & $E$ & $M$ & L & 1 & $\mathrm{~N}$ & & U & $\mathrm{N}$ & $E$ & A & $\mathrm{T}$ & $E$ & $N$ \\
\hline$E$ & & A & & L & & C & & $L$ & & A & & $\mathrm{L}$ & & $\mathrm{T}$ \\
\hline$D$ & 1 & $N$ & G & $Y$ & & $E$ & V & 1 & L & D & 0 & E & $\mathrm{R}$ & $S$ \\
\hline
\end{tabular}

\section{ET33 CrossworLd winners}

The winners of the Random House Word Menu, edited by Stephen Glazier (an innovative blend of thesaurus and dictionary), the prize for our January 1993 crossword, are:

R.J. Davison, Cambridge, England

Kelley Hayden, Iowa City, Iowa, U.S.A.

Derrick Jenkins, Stuttgart, Germany

R. Sutherland, North Hatley, Quebec, Canada Mrs Leila Ward, Bath, England

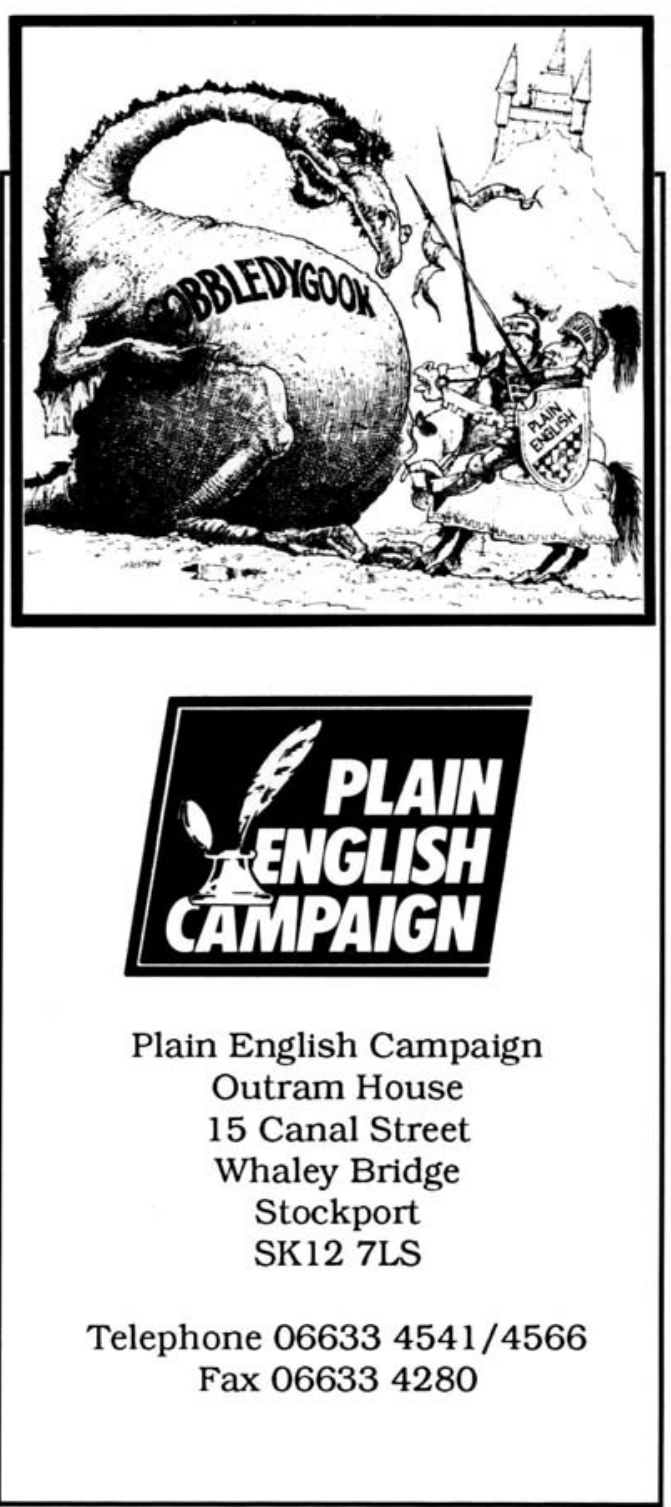

